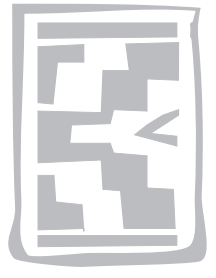

\title{
Detection of Anaplasma antibodies in wildlife and domestic species in wildlife-livestock interface areas of Kenya by major surface protein 5 competitive inhibition enzyme-linked immunosorbent assay
}

\author{
J.J.N. NGERANWA'1, 2, S.P. SHOMPOLE ${ }^{1}$, E.H. VENTER ${ }^{2}$, A. WAMBUGU ${ }^{1}$, \\ J.E. CRAFFORD² and B.L. PENZHORN²*
}

\begin{abstract}
NGERANWA, J.J.N., SHOMPOLE, S.P., VENTER, E.H., WAMBUGU, A., CRAFFORD, J.E. \& PENZHORN, B.L. 2008. Detection of Anaplasma antibodies in wildlife and domestic species in wildlifelivestock interface areas of Kenya by major surface protein 5 competitive inhibition enzyme-linked immunosorbent assay. Onderstepoort Journal of Veterinary Research, 75:199-205

The seroprevalence of Anaplasma antibodies in wildlife (eland, blue wildebeest, kongoni, impala, Thomson's gazelle, Grant's gazelle, giraffe and plains zebra) and domestic animal (cattle, sheep and goat) populations was studied in wildlife/livestock interface areas of Kenya. Serum samples were analyzed by competitive inhibition enzyme-linked immunosorbent assay (CI-ELISA), using a recombinant antigen (MSP-5) from Anaplasma marginale surface membrane. A monoclonal antibody, FC-16, was used as the primary antibody, while anti-mouse conjugated to horseradish peroxidase was used as the secondary antibody. The results indicate a high seroprevalence in both wildlife and livestock populations, in contrast to earlier reports from Kenya, which indicated a low seroprevalence. The differences are attributed to the accurate analytical method used (CI-ELISA), as compared with agglutination techniques, clinical signs and microscopy employed by the earlier workers.
\end{abstract}

Keywords: Anaplasma, CI-ELISA, Kenya, seroprevalence, wildlife-livestock interface

\section{INTRODUCTION}

Anaplasmosis is an infectious rickettsial disease caused by Anaplasma marginale and Anaplasma centrale in cattle and Anaplasma ovis in sheep and goats (Theiler 1910, 1911; Lestoquard 1924). The disease is acute or subacute in cattle, although sub-

* Author to whom correspondence is to be directed. E-mail: banie.penzhorn@up.ac.za

1 Kenya Agricultural Research Institute, P.O. Box 29231, Nairobi, Kenya

2 Department of Veterinary Tropical Diseases, Faculty of Veterinary Science, University of Pretoria, Private Bag X04, Onderstepoort, 0110 South Africa

Current address: Department of Biochemistry \& Biotechnology, Kenyatta University, P.O. Box 43844, Nairobi, Kenya

Accepted for publication 24 April 2008-Editor clinical infections are not uncommon. The severity of the disease in cattle is directly related to age: in animals less than 1 year it is usually subclinical; in yearlings and 2-year-olds it is moderately severe, and in older cattle it is severe and often fatal (Potgieter \& Stoltsz 2004). Sheep and goats often suffer only mild anaplasmosis, but occasionally goats suffer severe clinical disease (Splitter, Antony \& Twiehause 1956; Kimberling 1988; Shompole, Waghela, Rurangirwa \& McGuire 1989; Stoltsz 2004). Anaplasma phagocytophilum, previously known as Ehrlichia phagocytophila (Dumler, Barbet, Bekker, Dasch, Palmer, Ray, Rikihisa \& Rurangira 2001), occurs widespread in humans and domestic animals.

Anaplasmosis is widely distributed throughout tropical and subtropical areas of the world, as well as in some temperate areas (Soulsby 1982). The disease 
is common in Africa, the Middle East, southern Europe, the Far East, Central and South America and the United States of America (Soulsby 1982).

Anaplasma infections in wildlife, both natural and experimental, as well as occurrence of Anaplasma antibodies in wildlife have been reported world-wide (Kuttler 1984). Among African wildlife, subclinical occurrence of Anaplasma marginale, either natural or after artificial infection, has been confirmed in the African buffalo, Syncerus caffer (Potgieter 1979), eland, Taurotragus oryx (Peirce 1972; Ngeranwa, Venter, Penzhorn, Soi, Mwanzia \& Nyongesa 1998), black wildebeest, Connochaetes gnou (Neitz 1935), blue wildebeest, Connochaetes taurinus (Smith, Brocklesby, Bland, Purnell, Brown \& Payne 1974), grey duiker, Sylvicapra grimmia (Neitz \& Du Toit 1932) and blesbok, Damaliscus dorcas phillipsi (Neitz \& Du Toit 1932). Anaplasma marginale was successfully transmitted from a naturally infected giant African rat, Cricetomys gambianus, to a bovine (Dipeolu, Akinboade \& Adetunji 1981).

Subclinical occurrence of Anaplasma ovis, either natural or after artificial infection, has been confirmed in eland (Enigk 1942; Ngeranwa et al. 1998) and blesbok (Neitz 1939), and Anaplasma centrale can be artificially established in blesbok (Neitz \& Du Toit 1932).

The occurrence of unidentified Anaplasma spp., based on positive serological assays or presence of organisms visible on blood smear examination, has been reported in African buffalo (Brocklesby \& Vidler 1966), blue wildebeest (Brocklesby \& Vidler 1965; Kuttler 1965; Löhr \& Meyer 1973; Burridge 1975), Coke's hartebeest, Alcelaphus buselaphus cokei (Löhr \& Meyer 1973), Thomson's gazelle, Gazella thomsonii (Löhr \& Meyer 1973), Grant's gazelle, Gazella granti (Löhr, Ross \& Meyer 1974), gerenuk, Litocranius walleri (Brocklesby \& Vidler 1965), impala, Aepyceros melampus (Kuttler 1965; Löhr et al. 1974), sable antelope, Hippotragus niger (Grobler 1981; Thomas, Wilson \& Mason 1982), waterbuck, Kobus ellipsiprymnus (Kuttler 1965; Löhr et al. 1974) and giraffe, Giraffa camelopardalis (Brocklesby \& Vidler 1966; Löhr \& Meyer 1973; Augustyn \& Bigalke 1974; Löhr et al. 1974).

Giraffe would appear to be the only African wildlife species in which clinical anaplasmosis has been described in free-ranging animals. Severe clinical signs were reported in two cases (Löhr \& Meyer 1973; Augustyn \& Bigalke 1974). In both instances, death occurred in association with Anaplasma parasitaemia and severe anaemia. Anaplasmosis has been described in captive addax, Addax nasomaculatus (Ebedes \& Reyers 1984).

In the Coast Range area of California, Anaplasma spp. infections are maintained in black-tailed deer, Odocoileus hemionus, populations in the absence of cattle (Christensen, Osebold \& Douglas 1962). These deer also serve as reservoirs for infection of cattle. Anaplasma phagocytophilum can infect whitetailed deer, Odocoileus virginianus, and other cervids (Dugan, Yabsley, Tate, Mead, Munderloh, Herron, Stallknecht, Little \& Davidson 2006). The role of free-ranging African wildlife as reservoirs for infection of livestock has not been elucidated, however.

The major surface protein 5 (MSP-5) is conserved and regarded as a group-specific antigen among Anaplasma species. A MSP-5 recombinant protein together with a specific monoclonal antibody (MAB) (ANAF16C1) has been well characterized and when used in a competitive inhibition enzyme-linked immunosorbent assay (Cl-ELISA) they could detect group-specific antibody to all recognized Anaplasma species in cattle and goats (De Echaide, Knowles, McGuire, Palmer \& Suarez McElwain 1988; Visser, McGuire, Palmer, Davis, Shkap, Pipano \& Knowles 1992; Ndung'u, Aguirre, Rurangirwa, McElwain, McGuire, Knowles \& Palmer 1995; Knowles, De Echaide, Palmer, McGuire, Stiller \& McElwain 1996; Reyna-Bello, Cloeckart, Vizcaino, Gonzatti, Aso, Dubray \& Zygmunt 1998; Molloy, Bowles, Knowles, McElwain, Bock, Kingston, Blight \& Dalgleish 1999). This Cl-ELISA was used to detect group-specific antibodies to Anaplasma in wildlife-livestock interface areas in Kenya.

\section{MATERIALS AND METHODS}

\section{Study area}

This study was primarily carried out in the Machakos area of Kenya, where wildlife populations share the grazing with cattle, sheep and goats. A few specimens from other areas in Kenya were also included. Blood specimens were collected from eland $(n=$ $12)$, blue wildebeest $(n=58)$, kongoni, Damaliscus korrigum $(n=120)$, impala $(n=7)$, Thomson's gazelle $(n=8)$, Grant's gazelle $(n=5)$, giraffe $(n=3)$ and plains zebra, Equus quagga $(n=11)$ at the Athi River slaughter house, Machakos $(60 \mathrm{~km}$ south of Nairobi) and its surroundings during routine game cropping. Giraffe specimens $(n=13)$ were collected from Nakuru National Park (165 km northwest of Nairobi) and eland specimens from the field in the Nakuru region $(n=41)$ and Baobab Ranch, Mom- 
basa $(n=2)$. Sera from livestock were collected from the Machakos area, as well as from the Laikipia and Thika districts. The negative controls $(n=10)$ were from captive-born buffalo calves raised in tickfree surroundings (Wildlife Disease Research Project, Kabete, Nairobi, Kenya). In live animals, blood was collected by venipuncture from the jugular vein into $5 \mathrm{ml}$ tubes. Blood from shot or slaughtered animals was collected into tubes when the animal was exsanguinated. The blood was allowed to clot; the serum was decanted into stoppered tubes and frozen until processed in the laboratory.

\section{CI-ELISA}

The CI-ELISA with recombinant MSP-5 was modified from a previously described assay used to detect antibody against MSP- 5 in $A$. ovis infected goats (Ndung'u et al. 1995). The recombinant Anaplasma antigen MSP-5 and a MAB ANAF16C1, were supplied by Washington State University, USA. Antimouse antibody was produced and conjugated to horseradish peroxidase (HRPO) at the Biotechnology Section, Kenya Agricultural Research Institute, Kabete, Kenya.

Briefly, pAM104A-transformed E. coli XL-1 Blue was grown overnight in $50 \mathrm{ml}$ of Luria-Bertani broth containing $150 \mathrm{mg}$ of ampicillin per $\mathrm{ml}$. The E. coli was harvested by centrifugation at $1000 \mathrm{~g}$ for $10 \mathrm{~min}$ at $4^{\circ} \mathrm{C}$. The pellet was washed with $10 \mathrm{ml}$ of a modified proteinase inhibition buffer (PI buffer) $[50 \mathrm{mM}$ Tris-HC1 (pH 8.0) containing $5 \mathrm{mM}$ EDTA and $1 \mathrm{mM}$ phenylmethylsulfonyl fluoride]. The pellet was dissolved in $5 \mathrm{ml}$ PI buffer containing $1 \mathrm{mg}$ lysozyme per $\mathrm{ml}$ and incubated on ice for $20 \mathrm{~min}$. Nonidet $\mathrm{P}-40$ was added to a concentration of $1 \%$, the mixture was vortexed briefly and incubated on ice for $10 \mathrm{~min}$. The solution was sonicated twice on ice at 100 watts for 1 min pausing for $15 \mathrm{~s}$. After sonication the mixture was centrifuged at $12000 \mathrm{~g}$ for $20 \mathrm{~min}$ at $4^{\circ} \mathrm{C}$. The supernatant (the antigen) was recovered and was stored at $4^{\circ} \mathrm{C}$.

Before use, the MSP-5 antigen and ANAF16C1 MAB were titrated in a checkerboard titration to determine the optimum working dilutions. Immulon 2 plates (Dynatec-USA) were coated overnight at room temperature with $40 \mu l$ of antigen diluted with coating buffer (0.03 $\mathrm{M} \mathrm{NaHCO}_{3}, 0.015 \mathrm{M} \mathrm{Na}_{2} \mathrm{CO}_{3}, \mathrm{pH}$ 9.6). The following day the contents of the wells were discarded and the plates washed three times with PBS (pH 7.4) containing $0.05 \%$ Tween 20 (PBS-T). After washing, the coated plates were blocked by adding $200 \mu \ell$ of PBS-T containing $5 \%$ skimmed milk pow- der per well and incubated for $1 \mathrm{~h}$ at room temperature. After blocking and emptying the wells, $40 \mu \ell$ per well of neat test serum were added in duplicates. All the subsequent incubations were done at room temperature for $45 \mathrm{~min}$ with mechanical shaking. The following controls were included: the first row was left as the blank and only PBS was added to keep the wells from drying out; in the second row, $40 \mu \ell$ of freshly diluted ANAF16C1 MAB were added; in the third and fourth rows, 10 different known negative sera were added, each well with a different serum sample; in the fifth row, known positive serum was added. After incubation, the contents of the wells were discarded, $50 \mu$ of the ANAF16C1 MAB were added per well except for the blank row in which PBS was again added. The plates were incubated and then washed three times with PBS-T before $50 \mu \ell$ of the HRPO-conjugated anti-mouse antibody were added to each well, including the blank wells. Incubation was done as above. After this incubation, the plates were washed three times with PBS-T with 5 min soaking between each wash. The substrate [2,2'-azino-di(3-ethylbenzothiazoline sulfonate)] (ABTS) containing $0.05 \% \mathrm{H}_{2} \mathrm{O}_{2}(30 \% \mathrm{v} / \mathrm{v})$ was added, $100 \mu \ell$ per well, incubated at room temperature for $30 \mathrm{~min}$ and the optical density was determined in a spectrophotometer at $410 \mathrm{~nm}$ wave length. The cut-off values were computed by calculating the mean and standard deviations of the negative controls. Any value which was less than the product of the mean of the negative controls and three standard deviations was considered positive while any reading above this product, was considered negative.

\section{RESULTS}

The results are given in Table 1.

\section{DISCUSSION}

A high seroprevalence of Anaplasma antibodies was found in all species investigated (Table 1). These results are in contrast to those of Kuttler (1965), where only $7 / 117$ wildlife sera were positive for Anaplasma spp. on the complement-fixation test (CFT). In a more recent survey also using the CFT, only $1 / 10$ buffaloes from a ranch in Laikipia was seropositive to Anaplasma spp. (Kimber, Lubroth, Dubovi, Berninger \& DeMaar 2002). Prevalence rates in wildlife approaching $75 \%$ were reported by Löhr et al. (1974), based on the Card Agglutination Test (CAT) and the Indirect Fluorescent Antibody Test 
Anaplasma antibodies in wildlife and domestic species in wildlife-livestock interface areas of Kenya

TABLE 1 Seroprevalence of antibodies to Anaplasma spp. in various species at the wildlife/livestock interface in Kenya

\begin{tabular}{|l|l|c|}
\hline Species & District & No. positive \\
\hline Eland & Machakos & $\begin{array}{c}12 / 12(100 \%) \\
3 / 4(75 \%) \\
2 / 2(100 \%)\end{array}$ \\
\hline Nakuru & Mombasa & $56 / 58(96.5 \%)$ \\
\hline Kongoni & Machakos & $112 / 120(93.3 \%)$ \\
\hline Impala & Machakos & $7 / 7(100 \%)$ \\
\hline Thomson's gazelle & Machakos & $6 / 8(75 \%)$ \\
\hline Grant's gazelle & Machakos & $4 / 5(80 \%)$ \\
\hline Giraffe & Machakos & $3 / 3(100 \%)$ \\
& Nakuru & $11 / 13(84.6 \%)$ \\
\hline Plains zebra & Machakos & $8 / 11(72.7 \%)$ \\
\hline Cattle & Thika & $29 / 29(100 \%)$ \\
& Machakos & $31 / 31(100 \%)$ \\
$82 / 88(93.2 \%)$
\end{tabular}

(IFAT). The differences may arise from the different methods used, as well as species-specific differences.

The IFAT was significantly more sensitive for detection of cattle infected with Anaplasma spp. (97\%); the CAT and CFT were less so $(84 \%$ and $79 \%$, respectively) (Gonzalez, Long \& Todorovic 1978). In an experimental study in the USA, the CFT gave false positive and suspicious reactions when applied to serum samples of known Anaplasma-negative pronghorn, Antilocapra americana, bighorn sheep, Ovis canadensis, and elk, Cervus canadensis (Howe, Hepworth, Blunt \& Thomas 1964). False negative reactions also occurred with known positive deer sera. With the capillary tube-agglutination test, $96 \%$ accuracy was obtained with known negative wildlife sera, but $49 \%$ false-negative reactions occurred on known positive sera (Howe et al. 1964). It has also been shown that CF titres in Anaplasma-carrier deer fall to levels below the sensitivity of the diagnostic test (Christensen, Osebold \& Rosen 1958).

It is interesting to note that 27 black-faced impalas, A. m. petersi, in Northern Namibia were seronegative to Anaplasma on the CAT (Karesh, Rothstein, Green, Reuter, Braselton, Torres \& Cook 1997). Whether this was due to insensitivity of the test or dearth of vectors in an arid environment is a moot point.

The high seroprevalence $(72.7 \%)$ in plains zebras is of interest, as occurrence of Anaplasma spp. in zebras has apparently not been reported previously. Anaplasmosis has been reported in domestic horses; the causative organism in that case was named Anaplasma equi (Brion 1943). Anaplasma phagocytophilum should also be borne in mind. Although it has not been reported from African wildlife, A. phagocytophilum can infect horses (Madigan, Richter, Kimsey, Barlough \& Bakken 1995) and other livestock (Hoffman-Lehman, Meli, Dreher, Gönczi, Deplazes, Braun, Engels, Schüpbach, Jörger, Thoma, Griot, Stärk, Willi, Schmidt, Kocan \& Lutz 2004). Infected domestic animals could have been imported into Kenya, and $A$. phagocytophilum may have spread to wildlife. Serological cross-reactivity between Anaplasma marginale and Anaplasma phagocytophilum has been demonstrated (Dreher, De la Fuente, Hoffmann-Lehmann, Meli, Pustera, Kocan, Woldehiwet, Braun, Regula, Stärk \& Lutz 2005; Stirk, Alleman, Barbet, Sorenson, Wamsley, Gaschen, Luckschander, Wong, Chu, Foley, Bjoersdorff, Stuen \& Knowles 2007).

High seroprevalence was also found in bovines, sheep and goats, with overall prevalences of $97 \%$, $90 \%$ and $85 \%$, respectively (Table 1). Earlier work done in Kenya using the CFT on bovine sera found a prevalence of $26 \%$ of positive cases and $26 \%$ of suspicious ones (Kuttler 1965). In more recent work, where diagnosis was based only on clinical signs, the incidence of bovine anaplasmosis over a oneyear period was found to be $15-57 \%$ (Mulei \& Rege 1989). These findings could not have been accurate, as diagnosis based on clinical signs is not sensitive enough and subclinical cases and carrier animals would have been missed. The authors also used blood smears to confirm their diagnosis, a method that may not help as the organisms are known to disappear from the blood more than 16-26 days into the disease (Henning 1956; Ristic 1962). Other than the methods used, differences may also occur based on the area where the studies were carried out. It is noteworthy that the study area covered by Mulei \& Rege (1989) is a high-potential one where zero-grazing management is practised by most farmers. With this management, the number of vectors and carrier animals is minimal. The present study, on the other hand, focused on areas of wildlife-livestock interaction, which are generally more arid rangelands where tick control is practised to reduce tick burdens rather than to eradicate ticks. 
The high seroprevalence in Kenyan wildlife is not unique. Seroprevalence of up to $100 \%$ has been reported in wildlife at some localities in the USA, while at other localities it was zero, suggesting either a lack of vectors and/or carriers, or that sample sizes may have been too small (Jessup, Goff, Stiller, Oliver, Bleich \& Boyce 1993). In the Machakos area, where most of our samples came from, wildlife and livestock grazed together. The cattle reared on these farms are of indigenous breeds, hence relatively resistant to anaplasmosis (Soulsby 1982), which allows relaxed tick control. In most of these areas, theileriosis is also not common as the principal tick vector, Rhipicephalus appendiculatus, does not occur, providing yet another reason for not applying strict tick control measures. These reasons can explain the high prevalence rates obtained in this study.

The findings of this study confirm that wildlife carry Anaplasma organisms in Kenya and could serve as reservoirs of infection for domestic animals.

\section{ACKNOWLEDGEMENTS}

This study was financed by the Netherlands Government, through the Wildlife Disease Research Project, to whom we express our deep appreciation. We also thank the Director, Kenya Agricultural Research Institute (KARI), for availing time, money and facilities without which this work would not have been successful. We are grateful to Washington State University, USA, the Biotechnology Section of KARI and Dr E.S. Visser, of the ARC-Onderstepoort Veterinary Institute, South Africa, for providing some of the materials used for this study.

\section{REFERENCES}

AUGUSTYN, N.J. \& BIGALKE, R.D. 1974. Anaplasma infection in giraffe. Journal of the South African Veterinary Association, 45:229.

BRION, A. 1943. A new equine disease: Anaplasmosis and its causal parasite, Anaplasma equi. Comptes Rendues de l'Academie des Sciences, Paris, 217:709-710.

BROCKLESBY, D.W. \& VIDLER, B.O. 1965. Some parasites of East African wild animals. East African Wildlife Journal, 3: 120-122.

BROCKLESBY, D.W. \& VIDLER, B.O. 1966. Haematozoa found in wild members of the order Artiodactyla in east Africa. Bulletin of Epizootic Diseases in Africa, 14:285-299.

BURRIDGE, M.J. 1975. The role of wild animals in the epidemiology of bovine theileriosis in East Africa. Journal of Wildlife Diseases, 11:68-74.

CHRISTENSEN, J.F., OSEBOLD, J.W. \& DOUGLAS, J.R. 1962. Bovine anaplasmosis in the Coast Range area of California.
Journal of the American Veterinary Medical Association, 141:952-957.

CHRISTENSEN, J.F., OSEBOLD, J.W. \& ROSEN, M. 1958. Infection and antibody response in deer experimentally infected with Anaplasma marginale from bovine carriers. Journal of the American Veterinary Medical Association, 132:289292.

DE ECHAIDE, S.T., KNOWLES, D.P., McGUIRE, T.C., PALMER, G.H., SUAREZ, C.E. \& McELWAIN, T.F. 1988. Detection of cattle naturally infected with Anaplasma marginale in a region of endemicity by nested PCR and a competitive enzyme-linked immunosorbent assay using recombinant major surface protein 5. Journal of Clinical Microbiology, 36:777782.

DIPEOLU, O.O., AKINBOADE, O.A. \& ADETUNJI, A. 1981. Transmission of Anaplasma marginale from a naturally-infected wild African giant rat (Cricetomys gambianus, Waterhouse) to a calf in Nigeria. Veterinary Parasitology, 8:337339.

DREHER, U.M., DE LA FUENTE, J., HOFFMANN-LEHMANN, R., MELI, A.L., PUSTERIA, N., KOCAN, K.A., WOLDEHIWET, Z., RAUN, U., REGULA, G., STÄRK, K.D.C. \& LUTZ, H. 2005. Serologic cross-reactivity between Anaplasma marginale and Anaplasma phagocytophilum. Clinical and Diagnostic Laboratory Immunology, 12:1177-1183.

DUGAN, V.G., YABSLEY, M.J., TATE, C.M., MEAD, D.G., MUNDERLOH, U.G., HERRON, M.J., STALLKNECHT, D.E., LITTLE, S.E. \& DAVIDSON, W.R. 2006. Evaluation of whitetailed deer (Odocoileus virginianus) as natural sentinels for Anaplasma phagocytophilum. Vector-borne and Zoonotic Diseases, 6:192-207.

DUMLER, J.S., BARBET, A.F., BEKKER, C.P.J., DASCH, G.A., PALMER, G.H., RAY, S.C., RIKIHISA, Y. \& RURANGIRA, F.R. 2001. Reorganization of genera in the families Rickettsiaceae and Anaplasmatacese in the order Ricekttsiales: unification of some species of Ehrlichia with Anaplasma, Cowdria with Ehrlichia and Ehrlichia with Neorickettsia, descriptions of six new species combinations and designation of Ehrlichia equi and 'HE agent' as subjective synonymns of Ehrlichia phagocytophila. International Journal of Systematic and Evolutionary Microbiology, 51:2145-2165.

EBEDES, H. \& REYERS, F. 1984. Anaplasmosis in two captive addax. Proceedings of an International Conference, Wildlife Disease Association, 4:121-124.

ENIGK, K. 1942. Die Empfänglichkeit der Elenantilope für Anaplasma ovis und Eperythrozoon ovis. Deutsche Tropenmedizinische Zeitschrift, 46:48-52.

GONZALEZ, E.F., LONG, R.F. \& TODOROVIC, R.A. 1978. Comparisons of the complement-fixation, indirect antibody and card agglutination tests for the diagnosis of bovine anaplasmosis. American Journal of Veterinary Research, 39: 1538-1541.

GROBLER, J.H. 1981. Parasites and mortality of sable antelope Hippotragus niger niger (Harris, 1838) in the Matopos, Zimbabwe. Koedoe, 24:119-123.

HENNING, M.W. 1956. Animal diseases in South Africa, $3^{\text {rd }}$ ed. South Africa: Central News Agency, Ltd..

HOFFMAN-LEHMAN, R., MELI, M.L., DREHER, U.M., GÖNCZI, E., DEPLAZES, P., BRAUN, U., ENGELS, M., SCHÜPBACH, J., JÖRGER, K., THOMA, R., GRIOT, C., STÄRK, K.D.C., WILLI, B., SCHMIDT, J., KOCAN, K.M. \& LUTZ, H. 2004. Concurrent infections with vector-borne pathogens associated with fatal hemolytic anemia in a cattle herd in Switzerland. Journal of Clinical Microbiology, 42:3775-3780. 
HOWE, D.L., HEPWORTH, W.G., BLUNT, F.M. \& THOMAS, G.M. 1964. Anaplasmosis in big game animals: Experimental infection and evaluation of serologic tests. American Journal of Veterinary Research, 25:1271-1275.

JESSUP, D.A., GOFF, W.L., STILLER, D., OLIVER, M.N., BLEICH, V.C. \& BOYCE, W.M. 1993. A retrospective serologic survey for Anaplasma spp. infection in bighorn (Ovis canadensis) populations in California. Journal of Wildlife Diseases, 29:547-554.

KARESH, W.B., ROTHSTEIN, A., GREEN, W., REUTER, H.O., BRASELTON, W.E., TORRES, A. \& COOK, R.A. 1997. Health evaluation of black-faced impala (Aepyceros melampus petersi) using blood chemistry and serology. Journal of Zoo and Wildlife Medicine, 28:361-367.

KIMBER, K.V., LUBROTH, J., DUBOVI, E.J., BERNINGER, M.L. \& DEMAAR, T.W. 2002. Serologic survey of selected viral, bacterial, and protozoal agents in captive and free-ranging ungulates from Central Kenya. Annals of the New York Academy of Sciences, 969:217-223.

KIMBERLING, C.V. 1988. Disease of the blood and blood forming system, in Diseases of sheep, $3^{\text {rd }}$ ed., edited by R. Jensen \& B.L. Swift. Philadelphia: Lea and Febiger.

KNOWLES, D.P., DE ECHAIDE, S.T., PALMER, G. McGUIRE, T., STILLER, D. \& McELWAIN, T. 1996. Antibody against an Anaplasma marginale MSP5 epitope common to tick and erythrocyte stages identifies persistently infected cattle. Journal of Clinical Microbiology, 34:2225-2230.

KUTTLER, K.L. 1965. Serological survey of anaplasmosis incidence in East Africa, using the complement-fixation test. Bulletin of Epizootiological Diseases in Africa, 13:257-262.

KUTTLER, K.L. 1984. Anaplasma infections in wild and domestic ruminants: A review. Journal of Wildlife Diseases, 20:12-20.

LESTOQUARD, F. 1924. Deuxieme note sur les piroplasmoses du mouton en Algérie. L'Anaplasmose: Anaplasma ovis nov. sp. Bulletin de la Société Pathologique Exotique, 17:784787.

LÖHR, K.F. \& MEYER, H. 1973. Game anaplasmosis: The isolation of Anaplasma organisms from antelope. Zeitschrift für Tropenmedizin und Parasitologie, 24:192-197.

LÖHR, K.F., ROSS, J.P.J. \& MEYER, H. 1974. Detection in game of fluorescent and agglutination antibodies in intraerythrocytic organisms. Zeitschrift für Tropenmedizin und Parasitologie, 25:217-226.

MADIGAN, J.E., RICHTER, P.J., KIMSEY, R.B., BARLOUGH, J.E. \& BAKKEN, J.S. 1995. Transmission and passage in horses of the agent of human granulocytic ehrlichiosis. Journal of Infectious Diseases, 172:1141-1144.

MOLLOY, J.B., BOWLES, P.M., KNOWLES, D.P., McELWAIN, T.F., BOCK, R.E., KINGSTON, T.G., BLIGHT, G.W. \& DALGLEISH, R.J. 1999. Comparison of a competitive inhibition ELISA and the card agglutination test for the detection of antibodies to Anaplasma marginale and Anaplasma centrale in cattle. Australian Veterinary Journal, 77:245-249.

MULEI, C.M. \& REGE, J.E.O. 1989. An examination of the incidence of East Coast fever (ECF), anaplasmosis and babesiosis in the bovine in Kabete area of Kiambu District in Kenya. Bulletin of Animal Health and Production in Africa, 37:213-216.

NDUNG'U, L.W., AGUIRRE, C., RURANGIRWA, F.R., McELWAIN, T.F., MCGUIRE, T.C., KNOWLES, D.P. \& PALMER, G.H. 1995. Detection of Anaplasma ovis infection in goats by major surface protein 5 competitive inhibition enzyme-linked immunosorbent assay. Journal of Clinical Microbiology, 33: 675-679.
NEITZ, W.O. 1935. Bovine anaplasmosis: The transmission of Anaplasma marginale to a black wildebeest (Connochaetes gnou). Onderstepoort Journal of Veterinary Science and Animal Industry, 5:9-11.

NEITZ, W.O. 1939. Bovine anaplasmosis: The transmission of Anaplasma ovis and Eperythrozoon ovis to the blesbuck (Damaliscus albifrons). Onderstepoort Journal of Veterinary Science and Animal Industry, 13:9-16.

NEITZ, W.O. \& DU TOIT, P.J. 1932. Bovine anaplasmosis: A method of obtaining pure strains of Anaplasma marginale and Anaplasma centrale by transmission through antelope. Report of the Director of Veterinary Services and Animal Industry, Union of South Africa, 18:3-20.

NGERANWA, J.J.N., VENTER, E.H., PENZHORN, B.L., SOI, R.K., MWANZIA, J. \& NYONGESA (sic). 1998. Characterization of Anaplasma isolates from eland (Taurotragus oryx): Pathogenicity in cattle and sheep and DNA profiles analysis. Veterinary Parasitology, 74:109-122.

PEIRCE, M.A. 1972. Observations on endoparasites of some East African vertebrates. East African Wildlife Journal, 10: 231-235.

POTGIETER, F.T. 1979. Epizootiology and control of anaplasmosis in South Africa. Journal of the South African Veterinary Association, 50:367-372.

POTGIETER, F.T. \& STOLTSZ, W.H. 2004. Bovine anaplasmosis, in Infectious diseases of livestock, $2^{\text {nd }}$ ed., edited by J.A.W. Coetzer \& R.C. Tustin. Cape Town: Oxford University Press.

REYNA-BELLO, A., CLOECKART, A., VIZCAINO, N., GONZATTI, M.A., ASO, P.M., DUBRAY, G. \& ZYGMUNT, M.S. 1998. Evaluation of an enzyme-linked immunosorbent assay using recombinant major surface protein 5 for serological diagnosis of bovine anaplasmosis in Venezuela. Clinical and Diagnostic Laboratory Immunology, 5:259-262.

RISTIC, M. 1962. A capillary tube-agglutination test for anaplasmosis-A preliminary report. Journal of the American Veterinary Medical Association, 141:588-594.

SHOMPOLE, S., WAGHELA, S.D., RURANGIRWA, F.R. \& McGUIRE, T.C. 1989. Cloned DNA probes identify Anaplasma ovis in goats and reveal a high prevalence of infection. Journal of Clinical Microbiology, 27:2730-2735.

SMITH, K., BROCKLESBY, D.W., BLAND, P., PURNELL, R.E., BROWN, C.G.D. \& PAYNE, R.C. 1974. The fine structure of intra-erythrocytic stages of Theileria gorgonis and a strain of Anaplasma marginale isolated from wildebeest (Connochaetes taurinus). Zeitschrift für Tropenmedizin und Parasitologie, 25:293-300.

SOULSBY, E.J.L. 1982. Helminths, arthropods and protozoa of domesticated animals, $7^{\text {th }}$ ed. London: Baillière Tindall.

SPLITTER, E.J., ANTONY, H.D. \& TWIEHAUSE, M.J. 1956. Anaplasma ovis in the United States: Experimental studies with sheep and goats. American Journal of Veterinary Research, 17:487-491.

STIRK, N.I., ALLEMAN, A.R., BARBET, A.F., SORENSON, H.L., WAMSLEY, H.L., GASCHEN, F.P., LUCKSCHANDER, N., WONG, S., CHU, F., FOLEY, J.E., BJOERSDORFF, A., STUEN, S. \& KNOWLES, D.P. 2007. Characterisation of Anaplasma phagocytophilum major surface protein 5 and the extent of its cross-reactivity with $A$. marginale. Clinical and Vaccine Immunology, 14:262-268.

STOLTSZ, W.H. 2004. Ovine and caprine anaplasmosis, in Infectious diseases of livestock, $2^{\text {nd }}$ ed., edited by J.A.W. Coetzer \& R.C. Tustin. Cape Town: Oxford University Press. 
THEILER, A. 1910. Anaplasma marginale (gen. and spec. nova). The marginal points in the blood of cattle suffering from a specific disease. Report of the Government Veterinary Bacteriologist of the Transvaal, 1908-1909.

THEILER, A. 1911. Further investigations into anaplasmosis of South African cattle. First Report of the Director of Veterinary Research, Union of South Africa.

THOMAS, S.E., WILSON, D.E. \& MASON, T.E. 1982. Babesia, Theileria and Anaplasma spp. infecting sable antelope, Hip- potragus niger (Harris, 1838), in Southern Africa. Onderstepoort Journal of Veterinary Research, 49:163-166.

VISSER, E.S., McGUIRE, T.C., PALMER, G.H., DAVIS, W.C., SHKAP, V., PIPANO, E. \& KNOWLES, J.R. 1992. The Anaplasma marginale msp5 gene encodes a 19-kilodalton protein conserved in all recognised Anaplasma species. Infection and Immunity, 60:5139-5144. 